\title{
THE ISLAMIC ETHICS OF MITOCHONDRIA TRANSPLANTATION
}

\author{
Anke Iman Bouzenita ${ }^{1 *}$, Mohamed Elwathig S. Mirghani ${ }^{2,3}$ \\ AND IRWANDI JASWIR ${ }^{2,3}$ \\ ${ }^{1}$ Department of Islamic Sciences, College of Education, \\ Sultan Qaboos University, Oman. \\ ${ }^{2}$ Bioprocess and Molecular Engineering Research Unit, \\ Department of Biotechnology Engineering, \\ ${ }^{3}$ International Institute for Halal Research and Training \\ International Islamic University Malaysia, \\ Jalan Gombak, 50728 Kuala Lumpur, Malaysia. \\ *Corresponding author: anke_b_@hotmail.com \\ (Received: $5^{\text {th }}$ Sept. 2016; Accepted: $5^{\text {th }}$ May 2017; Published on-line: $1^{\text {st }}$ Dec. 2017)
}

\begin{abstract}
Biotechnology has opened a new chapter with the advent of mitochondria transplantation for cell-based therapy. Mitochondrial transplantation has successfully led to birth; however, cytoplasmic transplantation has caused apprehension since the mixing of human ooplasm from two different maternal sources may generate mitochondrial DNA (mtDNA) heteroplasmy in the offspring. Most Islamic legal verdicts on human cloning and somatic cell transfer are explicit as to its prohibition, due to the change of creation, mixing of lineage and other evaluations. Is mitochondria transplantation equivalent to human cloning in that genetic information is proliferated and does it, therefore, take the same legal rule? Are there possible benefits (mașālih) for medical treatment that may render mitochondria transplantation permissible, or are possible harms (mafāsid) overweighing? Or is it a completely different procedure, taking a different rule? The paper will investigate into these questions and discuss the dimensions of Islamic ethics on the issue.
\end{abstract}

ABSTRAK: Bioteknologi telah membuka ruang baru pada perkembangan pemindahan mitokondria terapi berasaskan-sel. Pemindahan mitokondria telah berjaya menghasilkan kelahiran; walau bagaimanapun, pemindahan sitoplasmik telah membawa kepada masalah lain, ini kerana percampuran telur manusia (ooplasm) daripada dua induk wanita yang berbeza bakal menghasilkan mitokondrial DNA (mtDNA) yang pelbagai (heteroplasmy) dalam jalur keturunan. Kebanyakan undang-undang Islam ke atas klon manusia dan sel pemindahan somatik adalah jelas dan nyata larangannya. Ini disebabkan oleh perubahan pada ciptaan, percampuran dalam keturunan, dan pelbagai tanggapan lain. Adakah pemindahan mitokondria sama dengan klon manusia dalam informasi genetik dibiakkan dan adakah, dengan ini membawa kepada peraturan undang-undang yang sama? Adakah kemungkinan kebaikan (mașālih) pada rawatan perubatan akan menyebabkan pemindahan mitokondria dibenarkan, atau kemungkinan keburukan (mafäsid) lebih berat? Atau adakah prosedur itu benar-benar berlainan, sehingga menyebabkan hukum berbeza digunakan? Kertas ini akan mengkaji persoalan-persoalan ini dan membincangkan tentang isu ini dari sudut etika Islam.

KEYWORDS: mitochondria; organelle; heteroplasmy; DNA; genome; Islamic ethics; harms (mafāsid); benefits (mașāliḥ) 


\section{INTRODUCTION}

The mitochondrion (plural mitochondria) is a large organelle found in the cytoplasm of all plant and animal (eukaryotic) cells. Mitochondrial proteins vary depending on the tissue and the species. In humans, 615 distinct types of protein have been identified from cardiac mitochondria. The mitochondrial proteome is thought to be energetically regulated and the mitochondrion has its own independent genome, containing 37 genes. Its inheritance is haploid; mitochondria are inherited through the maternal side only. Mitochondria (mt) are known as "the powerhouse of the cell" because they provide most of the chemical energy in the cell. They are also involved in other tasks in the living cells such as cellular respiration, cellular differentiation, cell death, maintaining control of the cell cycle and cell growth. Mitochondria have been implicated in several diseases, including mitochondrial disorders, cardiac dysfunction, heart failure and autism [1]. Mitochondria transplantation may take place on the embryonic level, before or after in vitro fertilization of an egg cell, or through the transplantation of unhealthy mitochondria in adult human cells. While the first scenario has in variations already taken place but has been legally endorsed after heated debates by the UK as the only state in 2015, the second scenario is, to our knowledge, still in a trial phase. Both scenarios need to be evaluated within an Islamic legal and ethical framework.

\section{THE PROCEDURE}

Embryonic $\mathrm{mt}$ transplantation intends to replace the dysfunctional, unhealthy $\mathrm{mt}$ of the intended mother, who is the only mt carrier, with the healthy mtDNA of a female donor. This may happen in two ways: (i) maternal spindle transfer (MST), where the mt of the affected egg cell is exchanged with healthy donor mitochondria before fertilization. This happens by removing the nucleus from the egg cell of the mother-to-be, then inserting this nuclear DNA into an enucleated donor egg with healthy mitochondria. After in vitro fertilization with the father's sperm, the embryo can be implanted into the mother's womb, resulting in a baby with nDNA from each mother and father and mtDNA from a female donor, the "third parent"; and (ii) pronuclear transfer (PNT) which takes place after fertilization, where the parental DNA (the zygote) is transferred from a cell with unhealthy $\mathrm{mt}$ to a fertilized donated egg with healthy mtDNA from the "third parent" that is vacated of its zygote [2]. Meanwhile, the adult $\mathrm{mt}$ transfer has, to our knowledge, so far taken place in vitro only. Elliott et al. have shown that the introduction of normal epithelial mitochondria into human cancer cells inhibit proliferation and increase drug sensitivity. For example, the introduction of normal mammary mitochondria into human breast cancer cells inhibits cancer cell proliferation and increases the sensitivity of the human breast cancer cell line (MCF-7) to the anticancer drugs such as doxorubicin, abraxane, and carboplatin. These results support the role of mitochondrial dysfunction in cancer and suggest the possible use of targeted $\mathrm{mt}$ for cancer therapeutics. The in-vivo scenario could be to insert healthy donor mt into cancerous cells to enhance reception of anticancer drugs, stop tumor growth or kill cancerous cells $[3,4]$.

\section{ISLAMIC EVALUATION}

The primary concerns regarding genetic engineering involving embryos and IVF procedures from the Islamic perspective are the illicit mixing of progeny, establishment of doubtful parenthood and changing of creation. Actual known and expectable harms (mafāsid) and benefits (mașāliḥ) will also be discussed. 


\subsection{Mixing of ansāb (Lineage)}

Recent research on the actual role of mtDNA suggests that many discoveries are yet to be expected, it is, therefore, premature to decide on the lacking importance of mtDNA for genetics [5]. The donor mtDNA may account for a minor percentage of the child's DNA [6], but it is clearly traceable. The status of the donor with regard to the child is, therefore, unclear, is she a mother, comparable to a foster mother, are her own children related to the mtDNA recipient? The introduction of DNA other than that of husband and wife who are legally married to each other and alive at the time of IVF and implantation of the embryo into the wife's uterus disturbs a very complex system with regard to legal rules of marriage, procreation, inheritance, the social system at large. The identity and descent of the created child become unclear. An analogy to organ transplantation is faulty as organ transplantation (of blood, heart, and kidney) does not change the recipient's DNA. The transplantation of reproductive organs (testicles, ovaries) is not permissible due to the mixing of descent [7]. In addition to the mixing of DNA (nuclear and mitochondrial) from different parents which is part of both MST and PNT procedures, PNT also involves the destruction of the zygote of a donor egg. Adult $\mathrm{mt}$ transplantation therapy seems unobjectionable with regard to a possible mixing of lineage provided that no harm is involved for donor and recipient. The main question would be in how far a mitochondria transplantation in, say, an adult breast cancer patient affects her germ line. Since progeny is already established for this patient, there seems to be no concern of a possible mixing of ansāb. It may, in fact, be comparable to a blood transfusion and could fall under the permissibility of medical treatment if it realizes benefits for the preservation of life. The case is still subject to scrutiny.

\subsection{Alternatives}

The existence of alternatives is vital to decide whether a case can be described as a necessity (darürah) from the Islamic point of view. An acute case of a necessity that renders the prohibited lawful (al-darürah tubịh al-mahzürah) could be claimed with the imminent danger of losing life and limbs to oneself or a family member. The existence of alternatives (here: in treatment) defies this. MtDNA transplantation as a "therapy" for infertility or to avoid unhealthy offspring is not a therapy for already existing human beings, but projected to births planned in the future. Searching for less objectionable ways of therapy is mandatory.

\subsection{Actual and Possible Harms}

Warding off harm has priority over acquiring benefit (Dar'u l-mafsadah awlä min jalb al-mașlahah). The consideration of actual known and expectable possible harms is, therefore, essential and may, if prevailing, be given priority over possible benefits, bringing a prohibition closer than permission [8]. The possibility of $\mathrm{mt}$ heteroplasmy and malignant genetic modification through mtDNA transplantation is not sufficiently researched. Preliminary research results seem to defy the idea [6], but more clinical trials with long-term observation will be needed. The average number of mothers transmitting mtDNA defects in the UK has been estimated at 150, for the US at 778 per year [9]. But not all affected carriers of unhealthy mtDNA will choose and be subject to this treatment, due to the risks for themselves and their offspring [10]. It is however not a benefit for the entire society, but rather for a small number. It is possible to expect that the procedures involved ('harvesting' donor eggs, transplanting the mt, IVF procedures) are costly and may defer funds from the research for other healing techniques [11]. A major concern that is not generally discussed involves the donation of egg cells. They need to be free from $\mathrm{mt}$ dysfunctions, and a large number of donor eggs need to be procured. Donating women 
need to undergo fertility treatment with known side effects. The commodification of human eggs is to be expected [11]. In addition, the availability of this "treatment" may turn into a 'moral obligation' or even pressure to use it and not give birth to children with genetic defects anymore.

\subsection{Actual and Possible Benefits (mașāliḥ)}

At first glance, the therapeutic results and prospects of $\mathrm{mt}$ transplantation seem to be promising in that embryos resulting from the procedure are healed of the mtDNA defect and the healing effect is passed on to their offspring. Embryonic mtDNA transplantation, however, involves an impermissible mixing of lineage (ansāb) through involving a third genetic parent. Possible benefits cannot outweigh this prohibition. With the rise in discoveries on the functioning of the mitochondria and their role in diverse diseases, more therapeutic uses not involving embryonic transfer may be found. The mașlahah involved in protecting and enhancing human life, however, is still in the stage of probability and not yet attested to. It affects a small group of people and is not a common benefit to society at large, one of the conditions that need to be met for the consideration of mașlahah in rendering the prohibited lawful [12].

\section{CONCLUSION}

In conclusion, genetic therapy, and the mt transplantation that belongs to it, may seem and be propagated as a promising cure for manifold diseases. However, the change of the genetic blueprint in a way that involves genetic material of a donor, leading to a 'threeparent-baby' is analogous to human cloning in that it 1) defies sunnat al-zawjiyah, the creation of human beings from pairs, 2) genetic material of a donor who is not legally married to the father of the embryo is fused - if only to a small extent - and passed on to the next generations, therefore the nasab (progeny) of that embryo as well as its relation to the donor and her family and descendants is doubtful, with manifold effects on the Islamic legal rules regarding, marriage, descent, inheritance, and others. It is premature to completely exclude unwanted side effects and expectable harms at this stage. The expectable harms with regard to embryonic mtDNA transplantation seem to exceed possible benefits. In addition, the existence of prohibiting evidence with regard to the introduction of a third parent renders the procedure illegal. As to $\mathrm{mt}$ transplantation in adults from adult donor mitochondria, there is still a need to assess possible harms and benefits.

\section{REFERENCES}

[1] Chan DC. (2006) Mitochondria: Dynamic Organelles in Disease, Aging, and Development. Cell, Volume 125(7):1241-1252.

[2] Baylis F. (2013) The ethics of creating children with three genetic parents, Reproductive Medicine Online 26: 531-534.

[3] Elliott RL, Jiang XP, Head JF. (2012) Mitochondria Organelle Transplantation: Introduction of normal epithelial mitochondria into human cancer cells inhibits proliferation and increases drug sensitivity. Breast Cancer Research and Treatment, 136:347-354.

[4] Elliott RL, Jiang XP, Head JF. (2014) Mitochondria Organelle Transplantation: The Mitochondrion, “An Intracellular Organelle for Cell-Based Therapy” Opinion Commentary. International Journal of Applied Science and Technology, 4(5):158-162.

[5] New Scientist: Three-parent babies: It's more messy than we thought. 17 September 2014, https://www.newscientist.com/article/mg22329871-600-three-parent-babies-its-more-messythan-we-thought/ 
[6] Barritt JA, Brenner CA, Matter HE, Cohen J. (2001) Mitochondria in human offspring derived from ooplasmic transplantation. Human Reproduction 16:513-516.

[7] IMANA (Islamic Medical association of North America) (1967) Islamic Medical Ethics (Publication 2), Section 4: F Organ Donation and Transplantation. Available at: https://c.ymcdn.com/sites/www.imana.org/resource/resmgr/Files/Publication2.pdf

[8] Al-Suyūṭ̂̄, J. (2007) Al-Ashbāh wa l-naẓā'ir fī qawă $\bar{c}^{\mathrm{c}}$ id wa furū $\bar{̄}^{\mathrm{c}}$ fiqh al-shāfi ${ }^{\mathrm{c}}$ iyyah, Beirut, Dar al-Kutub al-'Ilmiyyah.

[9] Gorman GS, Grady JP, and Turnbull DM. (2015) Mitochondrial Donation - How many women could benefit? The New England Journal of Medicine, 372:(9) 885-887.

[10] Baylis F. (2015) The truth about mitochondrial replacement, Impact ethics.

[11] Stammers T. (2015) The ethics of mitochondrial transfer. Lecture was given at the First International Bioethics Conference, Sultan Qaboos University, Muscat, Oman, March 2015.

[12] Al-Ghazālī AH. (1997) Al-Musțaṣfā fị cilm al-ușūl. Beirut. 